\title{
POLITIKK
}

SKANDINAVISK TIDSSKRIFT

FOR INTERNASIONALE STUDIER

Årgang 76, Nummer 3, side 193-216, 2018, ISSN 1891-1757, www.tidsskriftet-ip.no, Publisert oktober 2018

\section{Kvifor forhandle fred? Ein analyse av forhandlingsstart i den væpna konflikten i Colombia}

\author{
Bård Drange \\ funiorforskar, Norsk Utenrikspolitisk Institutt (NUPI)
}

\begin{abstract}
Samandrag
Konflikten i Colombia har i mange tiår vore tilsynelatande uløyseleg. Trass i mange fredsforsøk har den alltid blussa opp att. I denne artikkelen forsøker eg å forklare starten på forhandlingane i 2012 mellom den colombianske staten og FARC, den største geriljagruppa i landet. Eg hevdar den fundamentale forklaringa på at dei nådde forhandlingsbordet, ligg i den militære svekkinga av FARC på 2000-talet, som gjorde at geriljagruppa gradvis såg det naudsynt, for i det minste å nå nokre av måla sine, å slutte konflikten gjennom forhandlingar. Den nest viktigaste faktoren er endringa i leiarskapet i Colombia, der den nyvalde presidenten Juan Manuel Santos i 2010 såg ei politisk løysing som mogleg og meir attraktiv enn forgjengaren og tok pragmatiske grep for å skape ein levedyktig prosess. Også tredjepartar bidrog til sjølve gjennomføringa av ein trygg og hemmeleg prosess samt til tillit til prosessen. Forhandlingsstart i 2012 vert - ved bruk av structured focused comparison - samanlikna med fredsdialogen i Caguán (1999-2002) mellom dei same partane, der partane ikkje byrja forhandlingar. Case-studiar som denne kan hjelpe oss å forstå dynamikkar bak kvifor væpna aktørar vel ei politisk løysing på ein væpna konflikt. Forhandlingsstart, som eg analyserer, må ikkje likestillast med fredsavtale eller slutten på konflikten, men kan gje oss viktige svar på kor væpna aktørar sin motivasjon til å forhandle kjem frå, og under kva tilhøve denne motivasjonen kan bringe partane til forhandlingsbordet.
\end{abstract}

Nøkkelord: fredsforhandlingar • væpna grupper • konfliktløysing $\cdot$ Colombia

\footnotetext{
^Kontaktinformasjon: Bård Drange. Email: bardd@nupi.no

(C)2018 Bård Drange. This is an Open Access article distributed under the terms of the Creative Commons Attribution 4.0 International License (http://creativecommons.org/licenses/by/4.0/), allowing third parties to copy and redistribute the material in any medium or format and to remix, transform, and build upon the material for any purpose, even commercially, provided the original work is properly cited and states its license.

Citation: Bård Drange (2018). Kvifor forhandle fred? Ein analyse av forhandlingsstart $i$ den vapna konflikten i Colombia, 76 : 193-216. http://dx.doi.org/10.23865/intpol.v76.1196
} 


\section{Bård Drange}

\section{Introduksjon}

Konflikten i Colombia har i mange tiår vore tilsynelatande uløyseleg. Colombia sine revolusjonære væpna styrker (FARC), den største geriljagruppa i landet, har kjempa for maktovertaking i meir enn femti år. Det er gjort fleire forsøk på å skape fred, men konflikten har alltid blussa opp att.

Konflikten var på sitt mest intense frå midten av 1990-talet og ti år fram i tid. Fleire millionar colombianarar vart internt fordrivne, sivilbefolkninga vart utsett for overgrep og massakrar, og fleire og dødelegare militære konfrontasjonar førte til høge dødstal (Woody 2015; UCDP 2017). Forutan FARC og Den nasjonale frigjeringshæren (ELN), ei mindre geriljagruppe, hadde ulike paramilitære styrker slått seg saman til ein organisasjon som både kjempa mot FARC og ELN og kompliserte konfliktbiletet ytterlegare. Frå 1999 til 2002 heldt den colombianske regjeringa og FARC fredsdialog i ei demilitarisert sone i Caguán i det sørlege Colombia. Trass i store forhåpningar og internasjonal støtte såg ein få framsteg og liten vilje frå partane til å nærme seg kvarandre (Isacson 2003).

Etter drøye tre år med fredsdialog valde colombianarane i 2002 ein president med mandat til å nedkjempe FARC militært. President Álvaro Uribe (2002-2010) kalla FARC narkoterroristar og såg på dei som kriminelle utan politiske målsettingar. Samstundes var FARC framleis bestemt på å ta makta i Colombia. Konflikten verka uløyseleg, både militært og politisk.

I 2010 vart Juan Manuel Santos vald til president etter Uribe. Etter to år med hemmelege, førebuande samtalar mellom Santos-regjeringa og FARC på Havanna, Cuba, byrja partane sjølve fredsforhandlingane i 2012 på same stad. Kvifor valde partane å byrja fredsforhandlingar i 2012? Og kva endra seg frå dialogen i Caguán til 2012 ? I denne artikkelen argumenterer eg for at dei tre viktigaste faktorane var den militære maktbalansen, leiarskapet hjå den colombianske staten og tredjepartar. Den militære maktbalansen er viktig fordi den på slutten av 2000-talet gav eit klart signal til FARC om at utsiktene til ein militær siger vart dårlegare og dårlegare. Medan FARC var på offensiven rundt år 2000 og kringsette hovudstaden Bogotá, vart dei i løpet av 2000-talet pressa ut i periferien av eit mykje meir moderne og sterkare colombiansk militærvesen. Likevel er òg leiarskapet hjå den colombianske staten viktig. For medan Álvaro Uribe var fast bestemt på å vinne militært, var Santos open for ei politisk løysing. Trass i sitt eige politiske mandat, som var å halda fram i fotsporet til nettopp Uribe, tok Santos initiativ til dialog samt pragmatiske grep for å giere prosessen levedyktig. Også tredjepartar, fyrst og fremst FARC sin viktigaste eksterne allierte, Hugo Chávez, samt tilretteleggjarane Cuba og Noreg, spelte ei viktig rolle.

Artikkelen undersøker kvifor partane valde å inngå fredsforhandlingar i 2012 medan dei under fredsdialogen i Caguán ikkje kom seg vidare frå eit forstadium, såkalla pre-forhandlingar. For å få mest mogleg gyldige resultat bruker eg George og Bennet (2005: 67) sin structured focused comparison. Dette betyr å stille dei same spørsmåla til begge casar samt å sjå på eit spesifikt aspekt ved casene. Denne metoden er brukt for å betre kunne generere kunnskap også om det universet av casar 
som Caguán og Havanna representerer, nemleg forhandlingsstart. Dessutan har eg valt å samanlikna ein "positiv" (Havanna) og ein "negativ" case (Caguán), noko Stein (1989: 261) føreslår for å forstå betre kvifor nokre prosessar fører til fredsforhandlingar. Å sjå både på kvifor eit fenomen oppstår og kvifor det ikkje oppstår, kan auke forklaringsevna vår (Levy 2008: 7).

Det empiriske materialet består av 35 intervju med sentrale personar i fredsprosessane i Caguán og Havanna samt hovudsakleg colombianske ekspertar på konflikten. ${ }^{1}$ Forutan politiske og militære medlemmer av dei væpna aktørane, intervjua eg nasjonale og internasjonale tredjepartar i prosessen, colombianske og internasjonale ekspertar, samt leiarar av sivilsamfunnsorganisasjonar. I intervjua stilte eg fyrst alle respondentane eit ope spørsmål om kva faktorar dei meinte var viktigast for å forklare forhandlingsstart i Havanna, og mangel på dette i Caguán. Deretter drog eg nytte av den spesifikke respondenten sin ekspertise eller rolle i fredsprosessane. ${ }^{2}$ I analysen legg eg mest vekt på det majoriteten av respondentane argumenterer, og vurderer om argumenta som ligg bak held vann. Motargument er brukte til å nyansere og problematisere hovudargumentet. ${ }^{3}$

Denne studien fokuserer på Colombia, og han bidrar til å auke forståinga av kva faktorar som var viktigast for forhandlingsstart i 2012. Likevel kan funna mine bidra til å auke vår forståing av forhandlingsstart generelt. Ein lærdom er under kva forhold forhandlingar kan byrje. At dei byrja i Colombia i 2012 er spesielt, ettersom lågare konfliktintensitet og mindre politisk press kan bety færre intensiver til å forhandle. Ei anna lærdom handlar om korleis skifte i leiarskapet kan medverke til forhandlingsstart. Medan ein i fleire døme har funne endringar i leiarskapet viktig, står det framleis igjen å utforske fleire av dynamikkane bak. Desse spørsmåla kjem eg tilbake til i diskusjonen.

I artikkelen byrjar eg med å beskrive fredsprosessar og definere gjenstridige konfliktar. Deretter gir eg kontekst til den colombianske konflikten og dei to fredsprosessane eg undersøker. I hovuddelen av artikkelen analyserer eg fredsprosessane basert på mitt empiriske material. Til slutt konkluderer eg med å vurdere utsiktene for Colombia og implikasjonar for gjenstridige konfliktar generelt.

\section{Omgrep}

Fredsprosessar og forhandlingsstart

Sjølv om universet av fredsprosessar er mangfaldig, byrjar dei aller fleste med ein pre-forhandlingsfase (Stein 1989). I denne fasen vert partane samde om kva som er interessekonfliktane, og det vert utvikla ein agenda og ein metodologi. Er ein samde

\footnotetext{
${ }^{1}$ For liste over alle respondentar, sjå Drange (2017).

${ }^{2}$ Med Sandra Borda Guzmán, til dømes, fokuserte eg på hennar forskingsfokus: internasjonale aktørar. Med FN sin spesialutsending (1999-2002) Jan Egeland og Colombia sin fredsminister (1998-2000) Victor G. Ricardo fokuserte eg på fredsdialogen i Caguán.

${ }^{3}$ I seksjonen om leiarar, for eksempel, meiner mange leiarskiftet hjå FARC i 2008 var viktig, medan andre meiner det spelte ei mindre rolle. Dette nyanserer analysen.
} 


\section{Bård Drange}

om kva ein skal forhandle om, kor ein skal forhandle og med kven? Dersom ein vert samde om dette rammeverket, byrjar fase to: fredsforhandlingar. I løpet av fredsforhandlingane diskuterer ein substansielle og eksplisitte forslag til å løyse punkter på agendaen (Iklé 1964:3-4).

Fredsforhandlingar kan beskrivast på mange måtar og delast opp i endå mindre delar. Ein naturleg fellesnemnar er at prosessar kan stoppa opp, få eit tilbakefall, for så å sjå eit gjennombrot. Forhandlingsstart er ein viktig augneblink, og - meiner eg vil ofte representere det Zartman og Berman (1982: 87) kallar "a turning point of seriousness". Det treng ikkje å bety at forhandlingsstart er det einaste og viktigaste turning point i ein prosess, men han indikerer ein vilje hjå partane til å løyse konflikten politisk. Forhandlingsstart er i denne artikkelen definert som tidspunktet der to væpna aktørar set seg ned for å forhandle på bakgrunn av ein agenda og metodologi partane er samde om.

\section{Gjenstridige konfliktar}

Lange interne konfliktar vert etter kvart gjenstridige, og dei vert såleis karakteriserte av fleire fredsinitiativ og tilbakefall til krigføring over fleire tiår, utan at ein kjem nærare ei løysing (Bercovitch \& Kadayifci 2002: 114-15). Mange konfliktar som varer lenge, oppstår og førgår ofte i periferien og vert komplisert av narkotikahandel (Fearon 2004) og involvering av eksterne aktørar (Cunningham 2010). I tillegg til dette plar konflikten ofte skape fiendskap og hemnlyst og ikkje minst store lidingar blant sivile. Den harmen som såleis oppstår i lokal-befolkninga, skaper ekstra hindringar i ein fredsprosess.

\section{Bakgrunn: konflikten i Colombia}

Viktige element i det colombianske konfliktbiletet

Konflikten i Colombia har røter langt tilbake i tid. Heilt sidan kolonitida har landet opplevd fleire større og mindre krigar. Oppløpet til den siste konflikten starta i 1948, då den liberale presidentkandidaten Jorge Eliécer Gaitán vart drepen og landet vart kasta inn i ein tiårsperiode kalla "Valden" (La Violencia), ${ }^{4}$ ein spesielt valdeleg konflikt mellom det liberale og det konservative partiet i Colombia. Meir enn hundretusen vart drepne før partia i 1958 vart samde om å dele makta mellom seg. ${ }^{5}$ På 1960-talet oppstod det fleire kommunistinspirerte væpna grupper på den colombianske landsbygda, deriblant FARC i 1964 (Pécaut 2008: 37-38).

FARC vart danna under det opprørsgruppa sjølv kallar "invasjonen av Marquetalia", ein colombiansk militæraksjon mot sjølverklærte kommunistiske republikkar sør i Colombia (Chernick 2007: 54). Frå byrjinga av har jordreform vore den viktigaste kampsaka. Medan FARC ideologisk sett er marxistisk, er røtene frå

\footnotetext{
${ }^{4}$ Alle omsetjingar frå spansk og engelsk til norsk ved forfattar.

${ }^{5}$ Kring 193000 drepne frå 1948-1966, brorparten før 1953 (CNRR 2013: 115).
} 
den colombianske landsbygda og kampen mot ulikskap. Målsettinga til gruppa er å ta makta i Colombia. Etter to tiår med geriljakrig med låg intensitet vart FARC militært mykje sterkare på 1980- og 1990-talet, finansiert hovudsakleg av involvering i narkotikahandel, utpressing og kidnapping (Peña 2014; Grenoble \& Rose 2011).

FARC er ei svært hierarkisk gruppe, med Sekretariatet som det øvste organet. Manuel Marulanda ${ }^{6}$ var øvste leiar frå 1964 fram til sin død i 2008. Alfonso Cano, som tok over etter Marulanda, var leiar i tre år før han vart drepen av colombianske styresmakter i 2011. Etter Cano tok Timoleón Jiménez over og vart etter fredsavtalen leiar i FARC sitt nye politiske parti.

Forutan FARC har òg ELN kjempa mot staten i over femti år. ELN er ei mindre og mindre hierarkisk gruppe, som, liksom FARC, ved fleire høve har vore i dialog med den colombianske staten. Etter ei våpenkvile rundt årsskiftet 2017-2018 fortsette kampar mellom den colombianske staten og ELN i 2018. Begge partar har tidvis vist vilje til å forhandle, men prosessen er prega av fleire pausar, og partane er langt frå å nå ein fredsavtale. Ein annan sentral aktør er høgreorienterte paramilitære styrker, som i 1997 sameinte seg og etablerte paraplyorganisasjonen Colombia sine sameinte sjølvforsvarsstyrker (AUC). Paramilitære styrker vart til som sjølvforsvarsstyrker mot FARC, og dei har til tider i stor grad samarbeidd med segment av den legale colombianske hæren (Chernick 2007: 58; Grenoble \& Rose 2011:290). Store deler av AUC vart demobiliserte i perioden 2003-2005, men paramilitære styrker er framleis aktive i fleire mindre grupper.

Konflikten i Colombia har vore brutal; han har sidan 1964 totalt kravd kring 220000 menneskeliv, og kring 7 millionar har vorte internt fordrivne (CNRR 2013). Av desse 220000 er kring 30000 (UCDP 2017) rekna som soldatar falne i krig. Dette vitnar om kor mykje sivilbefolkninga har lidd.

\section{Om fredsprosessane}

Dei to fredsprosessane eg undersøker, Caguán (1999-2002) og Havanna fram til forhandlingsstart (2010-2012), kom til på svært ulike måtar og i ulike kontekstar. I ei folkeavrøysting organisert av sivilsamfunnet i Colombia i samband med parlamentsvalet i 1997, gav 10 millionar colombianararar eit sterkt mandat til den komande presidenten om å søke fred (Bouvier 2012: 53). Den nyvalde presidenten Andrés Pastrana (1998-2002) tok dette som sitt mandat og sa seg samd med FARC-leiar Manuel Marulanda sine krav til dialogen i juli 1998. Dei viktigaste av desse krava var å nedkjempe dei paramilitære og demilitarisere eit område på 42000 kvadratkilometer, på storleik med Sveits, der dialogen skulle finne stad (Isacsoon 2003: 8-9). Den 7. januar 1999 opna partane dialogen, men det skjedde utan at FARC-leiaren var til stades. Partane vart samde om ein agenda i mai 1999. Dei neste tre åra, avbrote av fem lengre pausar, haldt partane fleire offentlege debattar og nokre mindre møter mellom delegasjonane (Isacson 2003).

\footnotetext{
${ }^{6}$ Eg bruker, som litteraturen elles, FARC-medlemmer sine alias.
} 


\section{Bård Drange}

Fredsprosessen i Havanna byrja med den nyvalde presidenten Juan Manuel Santos sitt hemmelege brev til FARC ein månad etter innsettinga i 2010. Der anerkjente han FARC sine politiske mål og inviterte til dialog. FARC responderte ein månad seinare og sette dermed i gong ein to år lang hemmeleg prosess (Acosta 2016). Partane møttest ein gong nord i Colombia og deretter to gonger på ein venezuelansk militærbase på øya Orchila (Goméz Giraldo 2015: 27). Frå februar til august 2012 heldt partane formelle, men framleis hemmelege pre-forhandlingar på Cuba, der òg Noreg bidrog til tilrettelegging. Der vart partane samde om ein agenda og metodologi, og dei byrja sjølve forhandlingane i Havanna i november same året (Goméz Giraldo 2015).

\section{Teori: Kvifor byrjar væpna aktørar å forhandle?}

Det kan peikast på mange ulike forklaringar på kvifor væpna aktørar forhandlar. Det kan vere konfliktintensitet, økonomisk krise, skifte i folkeopinionen, gjensidig tillit, ekstern maktbalanse, mekling m.fl. (Pruitt 1997; Mason \& Fett 1996; Zartman 2000; Fixdal 2016). Denne artikkelen fokuserer på det mange teoretiske bidrag seier er det absolutt viktigaste for å forklare kvifor partar ønskjer å avslutte ein krig gjennom forhandlingar, nemleg partane sin vilje og sine insentiv til å gjere nettopp det (Pillar 2014; Ramsbotham et al. 2012; Iklé 2005; Pruitt 1997, 2005; Zartman 2000). I det følgjande introduserer eg tre viktige faktorar frå litteraturen. Eg byrjar med den mest fundamentale, den militære maktbalansen, og omtalar deretter leiarar og tredjepartar.

\section{Militær maktbalanse}

For kvar enkelt aktør er fordelen med militær siger at ein ikkje treng inngå kompromiss. Ei politisk løysing gjennom forhandlingar vil nødvendigvis inkludere kompromiss, der partane får litt og gir litt (Zartman og Berman 1982: 87). Ei politisk løysing, ifølgje Pillar (2014: 46-7), vil berre vere av interesse i dei følgjande tre situasjonane.

Den fyrste situasjonen er at ein væpna aktør er avhengig av motparten for å oppnå måla sine. Dette er ikkje tilfellet i borgarkrigar der målet er å tilintegjera opprørsgruppa eller å ta makta i landet. Den andre grunnen for å forhandle vil vere at ein aktør ikkje har den militære kapasiteten til å vinne. Med andre ord vil ein forhandle dersom siger er umogleg. Den tredje grunnen er at kostnadane ved å vinne militært, sjølv om det skulle vere mogleg, er for store. Kan hende vil det koste for mykje økonomisk, i menneskeliv, i politisk kapital osb. Her tenker ein, teoretisk sett, på all kostnad med å fortsetja krigføringa i så og så lang tid før ein eventuell siger. Det kan òg hende at å forhandle med fienden vil koste for mykje, for eksempel i form av politisk kapital og støtte frå eksterne og interne støttespelarar (Kaplow 2016).

Fleire forskarar har nyansert forståinga vår av kvifor partar vel å forhandle. Pruitt $(1997 ; 2005)$ meiner forhandlingsstart kan verte forklart av partane sin motivasjon til å forhandle og deira optimisme om at forhandlingar kan lukkast og på sikt gje avkastingar. Det er fleire som peikar på optimisme om å kunne nå avtale, og ei anerkjenning av at forhandlingar kan vere ein reell veg vekk frå krig (Pruitt 1997; 
2005; Zartman 2000; Fixdal 2016). Likevel er altså det viktigaste at aktørane siølve er villige til å sjå etter politiske løysingar (Pillar 2014; Ramsbotham et al. 2012).

For å forstå kva utsikter væpna aktørar har til å vinne militært, må ein undersøke den militære maktbalansen. For å undersøke denne meiner Iklé (2005: 20) ein må sjå på aktørane sine noverande militære kapabilitetar, deira potensial for å mobilisere i framtida samt den hjelpa dei kan få frå tredjepartar. Gitt dette, vil dei kunne overvinne motstandaren? For å kunne seie noko om når partar meiner kostnadar ved å vinne militært er for store, meiner Iklé ein må vurdere både inneverande og framtidige dødsfall, menneskeleg liding og økonomiske tap.

\section{Leiarar}

Leiarar er sentrale fordi det er dei som til slutt må tolke tilgjengeleg informasjon og ta avgjersler om strategisk retning basert på aktøren sine overordna mål. Den militære maktbalansen kan verte forstått på svært ulike måtar, også av leiarar på same side av konflikten. Dette forklarer den tyske militærteoretikaren Carl von Clausewitz med the fog of war, eit uttrykk han brukte for å referere til mengda usikker, falsk og motstridande informasjon som leiarar har for å vurdere ein konflikt (Clausewitz, Howard og Paret 1984: 117).

Difor meiner fleire at leiarar, og oftast endringar i leiarskapet, kan forklare kvifor væpna aktørar forhandlar. Eit element er at nye leiarar kan endre standpunkt frå hovudsakleg militær til hovudsakleg ein politisk strategi fordi han eller ho ikkje før har forplikta seg til eit anna alternativ (Mitchell 1995: 44). Dette er viktig, ettersom mange leiarar ikkje ønskjer å endre strategi midt i ein krig fordi dei har bygd den politiske plattforma si på nettopp ein militær siger (Fearon \& Laitin 2008: 40). Difor kan ein ny leiar løyse opp i tilsynelatande fastlåste konfliktar (Stedman 1997: 241).

Leiarar plar ofte giere strategiske kursendringar tidleg i leiarskapsperioden sin. Ei slik kursendring kan vere eit skifte frå ei hovudsakleg militær til politisk strategi (Ghosn 2010). Stedman (1997: 11) finn at dette var tilfellet i den zimbabwiske borgarkrigen, medan Pruitt (2007) i den nord-irske konflikten meiner leiarskapsendring ikkje var naudsynt ettersom ein gjorde fred med fienden trass fleire tiår med same leiar. Sjølv om ei endring i leiarskapet kan vere viktig, kan personlegdommen og bakgrunnen til leiarar ha viktige implikasjonar for det strategiske alternativet dei føretrekker i ein konflikt.

\section{Tredjepartar}

Ofte spelar eksterne aktørar, tredjepartar, ei viktig rolle i konfliktar i andre land. Dei kan påverke aktørane sin vilje til å byrja fredsforhandlingar på minst to måtar: (1) ved bruk av militære verkemiddel og (2) gjennom ikkje-valdelege måtar som til dømes mekling.

Ekstern militær støtte eller deltaking kan ha ulike konsekvensar. Cunningham (2010) meiner ekstern deltaking kan forlenge ein konflikt og gjere politiske løysingar 


\section{Bård Drange}

vanskelegare av to grunnar. Den fyrste er at ei politisk løysing no må ta omsyn til ein ekstra aktør med sine interesser og krav. Den andre er at eksterne aktørar ikkje kjenner på kostnadane ved krigen på same måten som dei nasjonale aktørane. Likevel kan òg tredjepartar bidra til ein slutt på konflikten, i nokre tilfelle til ein politisk slutt på konflikten, ved å slutte å gje eller å innføre militær støtte til ein av partane (Fearon \& Laitin 2008).

Tredjepartar kan òg bidra gjennom fredsmekling eller å oppmoda partane om å slutte konflikten politisk. Dei kan, for eksempel, hjelpe partane å komme i kontakt (Pillar 2014: 79). Tredjepartar kan òg, både før og under forhandlingar, auke tilgjengeleg informasjon om partane sine intensjonar og krav og kan difor gjere partane meir optimistiske med tanke på å finne "common ground” (Pruitt 1997: 240). Til slutt kan også ein god forhandlingsstad og hemmeleghald gjere at forhandlarar stoler meir på kvarandre (Pillar 2014: 80). Hemmeleghald kan mellom anna hindre involvering frå media og opposisjonen og andre potensielle spoilers (Pruitt 1997: 245-246).

Analytisk tilnærming: Ei militær versus politisk løysing

I det følgjande analyserer eg årsakene til forhandlingsstart i 2012. Viktige faktorar i litteraturen er, som vist ovanfor, den militære maktbalansen, leiarar og tredjepartar. I analysen er det avgjerande å forklare korleis, og under kva omstende, desse faktorane medverka til forhandlingsstart. For å seie noko om dette, undersøker eg i kva grad desse faktorane gjorde at dei væpna aktørane i Colombia lente seg meir mot ei militær eller politisk løysing. Med andre ord foreslår eg å seie at væpna aktørar i ein konflikt har to strategiske alternativ. Det eine alternativet er ei militær løysing (vidare militær krigføring). Det andre er ei politisk løysing (forhandlingar). For å avgjere om ein faktor er viktig eller ikkje, kan ein sjå på i kva grad denne påverkar den væpna aktøren sin overordna strategi i den eine eller andre retninga.

"Vidare krigføring" og "forhandlingar" vert her forstått som to midlar for å nå ei militær eller politisk løysing. Men det er eit viktig poeng at partar ikkje berre forhandlar eller berre fører krig: Ofte vil ein væpna aktør bruke begge verkemidla samtidig, uavhengig av kva verkemiddel ein har mest tiltru til. Med andre ord kan partar både nytta krigføring for å kjempe fram ei politisk løysing, men ein kan også bruke forhandlingar for å nærme seg militær siger. Dette handlar om at målet for begge partar eigentleg både er politisk kontroll og militært hegemoni. I litteraturen har det å forhandle for å bygge opp under ei militær løysing vorte kalla å forhandle med "kortsiktige interesser" (Ghosn 2010: 1057). Her bruker ein forhandlingar som taktikk for å nå andre mål enn fredsavtale (Iklé 1964: 27).

\section{Analyse: Kvifor valde partane å byrja fredsforhandlingar?}

I det følgjande analyser eg, basert på det empiriske materialet, tre viktige, men kvalitativt svært ulike, faktorar til at partane valde å forhandle i 2012 og kvifor dei ikkje gjorde det i Caguán. 
Militær maktbalanse: det militære styrkeforholdet endrar seg

Den militære maktbalansen er ifølgje respondentane den fundamentale grunnen til at partane byrja fredsforhandlingar i 2012. Med få unnatak nemnde respondentane fyrst den store endringa i styrkeforholdet mellom partane frå 1998 til 2010. Medan FARC var på offensiven på slutten av 1990-talet, var det den colombianske staten som var dét i 2010 .

På slutten av 1990-talet hadde FARC lagt bak seg fleire militære sigrar, som innebar storskala angrep på militærbasar. Dei hadde store finansielle ressursar og heldt kring eit halvt tusen colombianske soldatar og politi som gislar. Som president Pastrana skriv i sine memoarar, var det colombianske militærvesenet "demoraliserte" (Pastrana 2005: 40). For staten var situasjonen prekær. I tillegg til FARC kjempa dei mot opprørsgruppa ELN og narkotikakartellar. Paramilitære styrker skapte vidare kaos, i tillegg til at landet opplevde ein stor økonomisk krise rundt år 1999. Pastrana såg det naudsynt å bruke eigne finansar, samt bidrag frå allierte, til å styrke det colombianske militærvesenet. Forutan å oppfylle fredsmandatet folket hadde gitt han, var han nøydd til å bygge eit sterkare militærvesen for å gjenopprette kontroll over territoriet. Meir strategisk meinte Pastrana militær mobilisering kunne bidra til anten å presse FARC til forhandlingsbordet, eller dersom det ikkje skulle lukkast, å nedkjempe FARC militært (Borda Guzmán 2012: 57).

Likevel vart fredsdialog, Pastrana sitt store politiske mandat, motarbeidd av sterke krefter i landet og vart ikkje godt mottatt frå sentrale støttespelarar. Det colombianske militærvesenet samt USA - som på det tidspunktet gav stor støtte til anti-narkotika-operasjonar - vart meir og meir skeptiske etter kvart som dialogen fortsette utan resultat. FARC sine store krav til samfunnsendringar, samt utnytting av det demilitariserte området til narkotikahandel og militær mobilisering, var blant dei største utfordringane (Isacson 2003). USA støtta fredsforsøket i byrjinga, men såg liten framgang, og viste større interesse i å støtte Colombia militært. Også det colombianske militærvesenet var skeptiske frå byrjinga, spesielt då dei vart bedne om å evakuere eit område på $42000 \mathrm{~km}^{2}$ for at dialogen skulle finne stad (Isacson 2003). Fråværet av det colombianske militærvesenet i fredsdialogen i Caguán var eit av FARC sine største argument for kvifor fredsdialogen ikkje nådde fram. ${ }^{7} \mathrm{I}$ tillegg var den politiske og økonomiske eliten generelt skeptiske til å la FARC få innflytelse. Ein avtale med FARC i Caguán, gitt deira militære styrke, ville sannsynlegvis betydd at den colombianske staten måtte gi mykje og få lite. ${ }^{8}$

Den militære maktbalansen rett før og under Caguán er, som alltid er tilfelle i asymmetriske konfliktar, vanskeleg å avgjere. Likevel er det klart at den colombianske staten lei fleire tap på slagmarka i åra før Caguán og var på defensiven. Samtidig

\footnotetext{
7 ‘Aldecoa, Matías' (Luis Eliécer Rueda), medlem av den Høgare sentrale kommandoen i FARC, intervju 19.12.16, Bogotá.

${ }^{8}$ Carlos Arturo Velandia, analytikar, tidlegare medlem av Høgkommandoen i ELN, intervju 29.11.16, Bogotá.
} 


\section{Bård Drange}

var ikkje FARC nær militær siger. I USA snakka ein om at Colombia var på randen av å verte ein "failed state". Dette vert hardt kritisert av mange, som meiner dette overdreiv FARC sine sjansar for å ta Bogotá, og underspelar Colombia sitt militærvesen. ${ }^{9}$ Ein analyse av dei militære kapasitetane til FARC i forkant av Caguán viser at dei trass større angrep mot militærbasar og liknande, ikkje var i stand til å militært overmanne den colombianske staten. ${ }^{10}$ Ein indikator var manglande evne til å kontrollere større byar over tid. FARC sitt angrep på Mitú den 1. november 1998, ein svært perifer regionhovudstad på grensa til Brasil, syner dette. ${ }^{11}$ Sjølv om FARC ønskte å kontrollere byen i ein månad, tok colombianske spesialsoldatar han tilbake etter berre tre. ${ }^{12}$

Sjølv om FARC sine sjansar til innan kort tid å vinne militært var relativt små, var forhåpningane blant FARC-leiarane store. Fleire sentrale FARC-medlemmer meinte dei var på oppløpet - at militær siger var eit spørsmål om tid (Posso 2009: 1). Det syner også denne ytringa frå den militære leiaren Jorge Briceño, som viser ei triumferande geriljagruppe som ser lyst på militær siger: «Ser du kva eg kan gjere med 20000 menn? Tenk kva eg kan gjere med $40000 »{ }^{13}$

Trass i FARC si tru på militær siger, hadde dei likevel grunnar til å inngå fredsdialog. Mange respondentar, for eksempel Johnson ved International Crisis Group, ${ }^{14}$ meiner det å få politisk støtte og legitimitet både nasjonalt og internasjonalt var viktig motivasjon. Meir enn å nå ei politisk løysing, som dei fleste i opprørsgruppa truleg såg på som lite sannsynleg, var det ei moglegheit til å mobilisere militært og generere inntekter frå narkotikahandel. Dette, å få Pastrana til å demilitarisere området, var mogleg grunna FARC sin militære styrke og Pastrana sitt sterke ønske om å oppfylle sitt politiske mandat. Det var difor short-term calculations, som er begrepet Ghosn (2010) bruker, som best kan karakterisere FARC si tilnærming: Fredsforhandlingar vart ikkje brukte som eit strategisk mål, men som eit taktisk middel til å styrke den militære strategien.

Eit anna viktig element er FARC-leiar Manuel Marulanda sin frykt for ein amerikansk militær-intervensjon (Castro 2008: 105). Dette ville eventuelt drastisk endre militære utsikter og prioriteringar, noko som gjorde at FARC-leiaren såg seg nøydd til å vinne tid til å bygge seg opp militært - både for ein eventuell amerikansk invasjon og FARC sin siste offensiv i Colombia (Castro 2008: 105ff). Difor var, truleg, FARC-leiar Manuel Marulanda sitt mål i 1998: “å forhandle tre-fire rundar ... og forlate forhandlingane med eit godt renommé og vinne naudsynt tid til å førebu

\footnotetext{
9 Til dømes Daniel García Peña, Høgkommissær for fred i Colombia (1995-1998), intervju 11.11.16, Bogotá, sjå også Tate (2015).

${ }^{10}$ Marc Chernick, professor, intervju 23.11.16, Bogotá.

${ }^{11}$ Armando B. Mansilla, sosiolog, intervju 25.11.16, Bogotá; Luis Eduardo Celis, analytikar og journalist, intervju 10.11.16.

${ }^{12} \mathrm{~B}$. Mansilla, intervju.

${ }^{13}$ Kyle Johnson, analytiker, intervju 13.12.16, Bogotá.

${ }^{14}$ Johnson, intervju.
} 
seg på ein eventuell invasjon" (Castro 2008: 106). Fleire respondentar hevdar også dette. ${ }^{15}$ Kan hende var det likevel tilløp til tillit blant forhandlarane, mellom anna i løpet av eit besøk i Oslo i april 2000. Men, som FN sin spesialutsending til Colombia Jan Egeland (2007) skriv, var den litle tilliten som kanskje var tilstades i utlandet borte då delegasjonane kom att til Colombia. I 2017 meiner Egeland dette nok kan skuldast at den underliggjande viljen til å forhandle ikkje var tilstades, spesielt ikkje hjå FARC. ${ }^{16}$ Det var nok FARC-medlemmer som ønska ei politisk løysing, og at også Pastrana ønskte ei politisk løysing er nok sikkert. Men dei viktigaste og fleste FARC-leiarane lente seg mot ei militær løysing, noko også Pastrana gjorde, både når han innsåg FARCs manglande vilje til å forhandle og korleis den colombianske hæren, den colombianske eliten og USA arbeidde mot.

Mellom 2002 og 2010 skjedde det store endringar i konfliktbiletet og den militære maktbalansen. FARC hadde mista kring halvparten av styrkane sine (sjå Grafe 1), hadde ikkje dei same føreseielege inntektene og vart pressa lengre og lengre vekk frå byane og ut i jungelen. Dessutan hadde fleire tusen demobilisert (Peña 2014: 282). Det var no staten som var på offensiven.

Grafe I: FARC-medlemmar per år frå I964-20I5

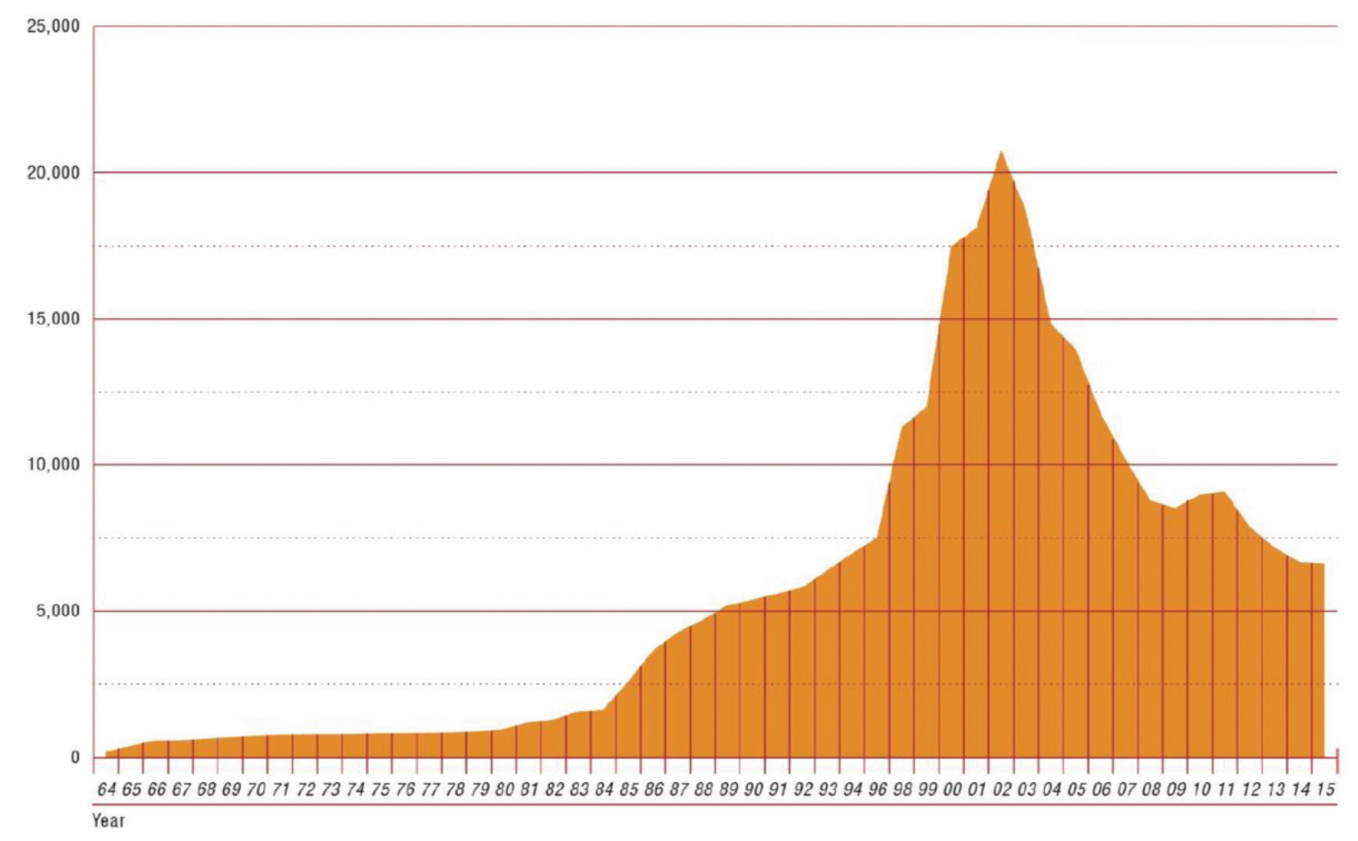

Grafe 1. Opphavleg frå den colombianske Høgkommisæren for fred sitt kontor, sitert i Echandía (2015). Denne grafen reprodusert frå ICG (2016: 31).

\footnotetext{
${ }^{15}$ Sandra Borda Guzmán, professor, intervju 13.12.16, Bogotá; Frédéric Massé, forskar Externado Universitetet, intervju 29.11.16, Bogotá.

${ }^{16}$ Jan Egeland, spesialutsending for FN til Caguán (1999-2002), intervju, 17.01.17, Oslo.
} 


\section{Bård Drange}

Den viktigaste grunnen til denne omveltinga er den store veksten i og mobilisering og modernisering av det colombianske militærvesenet. Frå kring 155000 soldatar og 100000 politi i 1998 (Vargas Velásquez 2012: 244), var dei oppimot ein halv million kring 2010. Det er med andre ord viktig å påpeike at moderniseringa og den militære veksten og mobiliseringa byrja under Pastrana sine fire år som president (1998-2002). Talet profesjonelle soldatar vart tredobla, totalt antal soldatar og talet på mobile brigadar vart dobla, og dei kjøpte fleire helikopter, etterretningsteknologi, fly med radar osb. (Vargas Velásquez 2012: 192). Men kanskje viktigare enn dette var den kvalitative utviklinga, der Colombia i løpet av 2000-talet utvikla større kapasitet i lufta, hadde overlegen teknologi og etterretning og drog nytte av dette i krigen mot FARC. USA si militære støtte gjennom Plan Colombia var eit viktig moment i denne, mellom anna i form av teknologi og etterretning (Grenoble \& Rose 2011).

Likevel, det er colombianske styrker, leia av Alvaro Uribe, som svekka FARC dramatisk i åra mellom Caguán og Havanna. Uribe vann presidentvalet i 2002 på ein politisk plattform om krig mot FARC, som han såg på som narkoterroristar utan politiske målsettingar. Uribe, frå starten av presidentskapet sitt, sette i gong ein meir organisert og effektiv, men også kontroversiell og kritisert, counterinsurgency mot FARC (Grenoble \& Rose 2011). Respondentane er i stor grad samde $i$ at svekkinga av FARC var den viktigaste faktoren for at partane inngjekk forhandlingar i 2012. Medan FARC tidleg på 2000-talet hadde omringa Bogotá, var dei etter få år ingen direkte trussel mot hovudstaden. Trass militær svekking var ikkje FARC militært beseira og kunne framleis yte stor militær motstand (Peña 2014).

I min analyse finn eg den militære svekkinga som den viktigaste av tre relaterte dynamikkar. Forutan fleire tap på slagmarka, var det også større misnøye internt i geriljagruppa, og infiltrering av FARC-soldatane førde til mistillit innanfor deler av gruppa (Pécaut 2008). Dette bidrog også til at fleire FARC-soldatar demobiliserte spesielt mot slutten av 2000-talet. Her var demobiliseringa av den paramilitære paraplyorganisasjonen AUC viktig, ettersom det også gav FARC-medlemmer ei moglegheit og insentiv til å demobilisere (Grenoble \& Rose 2011: 299).

Ein annan dynamikk er drapa på fleire sentrale FARC-leiarar, inkludert nestleiar Raul Reyes i 2008 og den militære leiaren Mono Jojoy i september 2010. Elles døydde også grunnleggjaren og den historiske leiaren Manuel Marulanda av naturlege årsaker i 2008. President Santos sjølv, saman med fleire respondentar, meiner det at FARC-leiarar frykta for eigne liv, var ein viktig faktor (Goméz Giraldo 2015: 23).

Den tredje dynamikken er politisk isolasjon, som delvis kom av den sterke narkoterrorist-diskursen til Uribe, og som vart forsterka av kidnapping og usikker finansiering frå involvering i narkotikahandelen, bruk av landminer osb. (Peña 2014). Opposisjonen mot FARC nådde eit høgdepunkt rundt 2008, då det vart arrangert store demonstrasjonar mot FARC over heile landet (Ibid: 267). Castellanos 
meiner FARC forstod at ettersom den colombianske staten fortsette krigføringa mot FARC, ville dei lide aukande politisk isolasjon. ${ }^{17}$

For å forklare kvifor partane valde å forhandle i 2012, må ein altså ta den militære maktbalansen og viktige relaterte dynamikkar i betraktning. FARC såg i aukande grad utover 2000-talet at å overta makta militært vart stadig vanskelegare. Som FARC-leiar Timoléon Jiménez uttrykker det, var FARC naturlegvis pressa mykje meir tilbake før Havanna enn i Caguán - spesielt grunna bruk av flyvåpen (Lozano 2016: 66). Trass i militær motgang var FARC-leiarar klare på at dei kunne overleve i 50 år til. ${ }^{18}$ Med frykt for auka politisk isolasjon, frykt for eigne liv og det som kunne vere ein moglegheit til å forhandle med Santos-regjeringa, var FARC opne for ei forhandla løysing.

\section{Leiarar}

Hjå den colombianske staten hadde endringa i leiarskapet store implikasjonar for den subjektive vurderinga av militær siger. Trass $\mathrm{i}$ at Uribe tok halvhjerta initiativ til ein slags fredsprosess i 2008 og 2010 (Acosta 2016: 70 og 131), var dette utan å anerkjenne FARC sine politiske målsetningar og vise vilje til å inngå politiske kompromiss. Juan Manuel Santos, derimot, såg ei politisk løysing som ønskeleg og mogleg frå staten si side, også fordi han nok ikkje vurderte ei militær siger på kort sikt som sannsynleg, og vidare kostnadar ved krig store (Chernick 2015: 144). Dette fordrar ei nøyare gransking av leiarskapa sine roller.

Endringa i leiarskapet frå Uribe til Santos i 2010 såg ikkje i byrjinga ut til å ha ei stor innverknad på konflikten eller ein mogleg fredsprosess. Santos hadde trass alt vore Uribe sin forsvarsminister frå 2006-2009, og hadde dimed stått sentral i krigen mot FARC. Men allereie tre dagar etter innsettinga i 2010 tok Santos kontakt med Venezuela sin leiar Hugo Chávez, som Santos visste var FARC sin viktigaste eksterne allierte og som kunne hjelpe i ein eventuell fredsprosess (Goméz Giraldo 2015). Ein månad seinare tok han kontakt med FARC gjennom det hemmelege sendebodet Henry Acosta. For å vise vilje overfor FARC refererer respondentar også til arbeidet hans med Loven for offer og tilbakegivelse av land, som offisielt anerkjenner den væpna konflikten i Colombia, som Uribe hadde nekta for at eksisterte. ${ }^{19}$ Respondentar peikar òg på ein strategisk involvering av tredjepartar og ekspertar i fredsprosessen som pragmatiske grep for å skape ein levedyktig prosess.

Mange meiner Santos som person er viktig for å forklare den colombianske staten si tilnærming til konflikten. Fleire teoretikarar hevdar som nemnt tidlegare at eit skifte i leiarskap kan drive fram ei endring i val av strategi. Medan Santos var overbevist om at ei politisk løysing var mogleg og ønskeleg, pressa Uribe på for ei

\footnotetext{
${ }^{17}$ Hugo Hernán Castellanos Jimenez, tidlegare oberst i Colombia sitt militærvesen, intervju 29.11.16, Bogotá.

${ }^{18}$ Dag Nylander, Noregs spesialutsending til Havanna (2011-2016), intervju 08.02.17, Oslo.

${ }^{19}$ Sergio Guarin, analytikar, intervju 17.11.16, Bogotá.
} 


\section{Bård Drange}

militær løysing. Uribe var for så vidt interessert i å ende krigen, men ikkje før han hadde "knekket ryggen deres militært" (Egeland 2007: 75). Uribe nekta dessutan å diskutere FARC sin politiske agenda, som han meinte ikkje eksisterte (Borda Guzmán 2012: 31). I motsetnad til Uribe, anerkjende Santos FARC sine politiske mål i sitt fyrste brev til FARC, der han skreiv at FARC sin motivasjon var gyldig, men at det er "metoden dei bruker som skadar nasjonen" (Acosta 2016: 204).

Det er ikkje utenkeleg at også ein annan presidentkandidat kunne tatt initiativet Santos tok. Likevel, den politiske risikoen han tok, og den evna han viste til pragmatisk å få sentrale brikker på si side, samt skaffe nok støtte for prosessen i eit Colombia der Uribes militære strategi var svært populær, antydar at Santos var svært viktig for å få i stand forhandlingar i 2012. Men at det militære styrkeforholdet var den viktigaste faktoren, indikerer at den konteksten Santos tok initiativet i var viktig. Det seier han også sjølv, og peiker på nettopp maktbalansen, samt også at FARC-leiarar følte seg sårbare og at det var regional støtte for fred i Latin-Amerika (Giraldo Goméz 2016: 23).

Ei samanlikning med Pastrana sin innsats i Caguán høver seg. Respondantane påpeiker nemleg fleire manglar med Pastrana sin innsats; sjølve fredsdialogen var taktisk dårleg førebudd, ${ }^{20}$ prosessen var kaotisk og usamanhengande, ${ }^{21}$ og Pastrana sjølv var naiv med tanke på kva ein slik fredsprosess faktisk kravde. ${ }^{22}$ Gitt den manglande støtta til ein fredsprosess frå mellom anna den colombianske hæren og eliten, og gitt FARC si tiltru til militær siger, kunne nok ingen leiar provosert fram forhandlingsstart i Caguán. Medan ein leiar kan vere ein spoiler (Stedman 1997) og ta pragmatiske grep for å få til fredsforhandlingar, har politiske leiarar avgrensa handlingsrom for å endre ein militær-politisk kontekst i eit avgrensa tidsrom.

For å forklare dei to presidentane sine ulike tilnærmingar til konflikten trengst ei grundigare analyse av bakgrunn og personlegdom. For det fyrste kjem Uribe og Santos frå forskjellige familiar med ulike bakgrunnar og delvis økonomiske interesser. Medan Uribe representerer dei store landeigarane i Colombia, er Santos del av ein tradisjonell og urban elite som kanskje endå meir enn Uribe er interessert i og avhengig av det internasjonale samfunnet. Fleire peiker også på FARCs drap på Uribes far som relevant for å forklare hans uvilje til å forhandle med FARC (Pécaut 2008: 62). For FARC representerer Uribe den eigentlege fienden, ${ }^{23}$ dei som hindrar colombianske bønder frå å eige eigen jord og som bidrar til auka ulikskapar på landsbygda.

Likevel såg ikkje FARC store forskjellar på Uribe og Santos i 2010. Santos hadde trass alt vore ei sentral brikke som forsvarsminister under Uribe 20062009, og begge representerte - for FARC - den økonomiske og politiske eliten i

\footnotetext{
${ }^{20}$ Han aksepterte FARCs krav om å demilitarisere eit område på $42000 \mathrm{~km} 2$ utan å forhandle, Álvaro Villarraga, forskar, intervju 13.12.16, Bogotá.

${ }^{21}$ Villarraga, intervju; Egeland, intervju.

${ }^{22}$ García-Peña, intervju.

${ }^{23}$ Armando, intervju.
} 
Colombia. ${ }^{24}$ For Santos er den økonomiske og politiske bakgrunnen sentral i hans oppfatning av konflikten og dei moglegheitene han såg i å få han avslutta. Forutan fred i seg sjølv og ønsket om å vere den som fører Colombia inn i fredstid, var Santos motivert av dei potensielle økonomiske gevinstane ved å slutte konflikten. Fleire gonger nemnde han at slutt på konflikten kunne auke årleg økonomisk vekst med ein til to prosent (Gillespie 2015). Som del av dette stod òg modernisering av landet, utnytting av naturressursar og utanlandsinvesteringar sentralt. Denne motivasjonen er viktig både for å forstå kva Santos ønskte med Colombia, men også fordi det gav han ein klar motivasjon for å byrje risikofylte forhandlingar med FARC. For å byrje forhandlingar var også personlegdommen hans relevant. Å sjå potensielle gevinstar langt fram $\mathrm{i}$ tid handlar litt om den pragmatiske tilnærminga han hadde til prosessen. Dessutan var risikoen for nederlag stor, noko som kunne sverte Santos sjølv og forårsake ein lengre periode utan kontakt mellom partane.

Eit viktig poeng er at leiarar plar endre strategi i ein konflikt tidleg i leiarskapet sitt (Ghosn 2010; Pruitt 2005). På den måten kan ein også vere den som ser konflikten og fredsavtalen giennom (Mitchell 1995: 45). Om ein har bygd den politiske plattforma si på krig, derimot, er det vanskeleg å gå vekk frå denne. For Uribe sin del var krigen mot FARC og betring av tryggleiken i landet viktige blant det som hadde gjort han svært populær hjå befolkninga. Nokre meiner Uribe trengte FARC, fienden, for å føra vidare sitt politiske prosjekt (Fergusson et al. 2016). For Santos, derimot, var byrjinga på presidentperioden ei moglegheit til å stake ut ein ny kurs og bygge sitt eige politiske prosjekt. Som ein del av dette meiner mange respondentar at forståinga hans av både det politiske og militære var sentralt. Nokre meiner han på bakgrunn av denne rolla betre forstod fordelar og ulemper med militære versus politiske verkemiddel, og at han mykje betre visste korleis han kunne utnytte politisk det militær-strategiske overtaket den colombianske staten hadde fått over FARC. ${ }^{25}$

Mange respondentar meiner også at leiarskapsskiftet i FARC i 2008 frå Manuel Marulanda til Alfonso Cano var viktig. Fleire peiker på Cano sin bakgrunn frå det Nasjonale Universitet i Bogotá, og som ein sentral person i den meir politiske fløyen av FARC, for å forklare kvifor han var meir positiv til og klar for å leie FARC inn i ein politisk prosess. ${ }^{26}$ Andre peikar på at Cano trass alt hadde vore del av FARC sitt øvste organ i fleire tiår, og at ei stor endring i kurs etter dødsfallet til den internt høgt respekterte og historiske leiaren Marulanda var usannsynleg. ${ }^{27}$ Eit anna element er at FARC, i si tilnærming til konflikten, ønskte å bruke både politiske og militære

\footnotetext{
24 'Matias Aldecoa' (Luis Eliécer Rueda), medlem av FARCs høgare sentralkommando og FNs verifisering av fredsavtalen, intervju.

${ }^{25}$ Jairo Rolando Delgado Mora, tidlegare sjef i politiet og direktør for det colombianske politiet sitt etterretningsorgan, intervju 22.11.16, Bogotá.

${ }^{26}$ Chernick, intervju; Juan Esteban Ugarriza, professor, intervju 16.11.16, Bogotá; Carlos Medina Gallego, professor, intervju 30.11.16, Bogotá.

${ }^{27}$ Sergio Guarin, intervju.
} 


\section{Bård Drange}

verkemiddel for å nå måla sine. Å skulle forhandle var difor ved fleire anledningar i løpet av konflikten sett på som naturleg og gunstig.

Det er sannsynleg at leiarskapsskiftet frå Marulanda til Cano var viktig, men kanskje endå viktigare var det større generasjonsskifte i Sekretariatet som dette skiftet reflekterte. Dette generasjonsskiftet kan hjelpeoss å forklare FARC sin gradvise dreiing mot ei politisk løysing mot slutten av 2000-talet. Ei endring er ei forskyving frå militærstrategar til fleire og meir politisk aktive medlemmar. Ei relatert forskyving er at medlemmer i Sekretariatet i minkande grad kom frå den colombianske landsbygda og i aukande grad frå politiske miljø i dei store byane, gjerne med utdanning frå utlandet. ${ }^{28}$ Fleire respondentar foreslår at dei meir politiske leiarane frå det urbane Colombia hadde meir erfaring med og interesse i å kjempe vidare for FARC sine målsettingar i politikken.

\section{Tredjepartar}

Eksterne aktørar har spelt mangslungne roller i den colombianske konflikten. Forutan oppmoding om å søke ei politisk løysing og tilrettelegging for denne, har USA spelt den viktigaste rolla av eksterne aktørar. Trass offentleg verbal støtte til fredsdialogen i byrjinga, vart USA tidleg svært skeptiske til fredsprosessen i Caguán, og dei trua mellom anna med å trekke støtta til Colombia dersom Pastrana gjekk FARC i møte for å restarte dialogen (Farah 1999). USA var i staden svært interessert i å styrke det colombianske militære apparatet, både i krigen mot narkotika og i krigen mot FARC, som dei såg på som ein stor trussel for Colombia. I USA vart Colombia presentert som ein "failed state" 29 og FARC som den sentrale narkotikaaktøren (Tate 2015: 47-48). Dette var ei klar overdriving, då paramilitære og narkotikakartellar vert rekna som mykje meir aktive enn FARC. Men dette fiendebiletet var med på å mogleggjere støtta til Plan Colombia i USA (Tate 2015).

Sjølv om USA presenterte Plan Colombia som eit fredsbidrag, hadde det ein negativ effekt på fredsdialogen i Caguán. Likevel er det usikkert om USA sin vilje til å støtte krigføring og narkotikaoperasjonar framfor sjølve fredsdialogen hindra forhandlingsstart. Mellom andre Borda Guzmán (2012), Tate (2015) og GarcíaPeña ${ }^{30}$ poengterer at regjeringa til Pastrana var ein vel så stor pådrivar som USA i utarbeidinga av Plan Colombia. Dei tok tidleg kontakt med amerikanarane for det Pastrana kalla ein "Marshall-plan for Colombia" (Tate 2015: 142), men som gjennom forhandlingar med amerikanarane raskt fekk eit meir militært preg. For Pastrana var dette ei moglegheit til å forsterke den militære mobiliseringa for å kjempe mot FARC og kontrollere eige territorium. Amerikansk støtte kan nok ikkje seiast i seg sjølv å ha forhindra forhandlingsstart, men trusselen om amerikansk involvering eller intervensjon i konflikten gjorde det viktigare for FARC å

\footnotetext{
${ }^{28}$ Medina Gallego, intervju; Chernick, intervju; Ugarriza, intervju. Sjå også Pécaut (2008: 79).

${ }^{29}$ García-Peña, intervju.

${ }^{30}$ García Peña, intervju.
} 
mobilisere militært. Som FARC-leiar Marulanda angiveleg sa i 1998, vurderte dei allereie då konsekvensane av ein militær involvering frå USA og militær opprusting som naudsynt (Castro 2008: 116).

Mellom Caguán og Havanna såg ein resultata av den militære støtta frå USA. Frå starten av Plan Colombia i 2000 og fram til 2016 spytta USA inn nesten 10 milliardar dollar, av dette 71 prosent av militær karakter (WOLA 2016). Denne støtta kan ha bidrege til å forlenge konflikten. Noko som er enklare å stadfesta, er den viktige rolla amerikansk militær støtte til modernisering, etterretning og luftkapasitet spelte i svekkinga av FARC. Sjølv om Plan Colombia ikkje var i nærleiken av å nå hovudmålsetjingar om anti-narkotikaoperasjonar (Tate 2015), bidrog støtta til å styrke Colombia sitt militærvesen og auke politiressursar. Eit eksempel på dette er angrepet på nestleiar i FARC Raul Reyes i ecuadoriansk territorium rett sør for grensa til Colombia, der amerikansk teknologi i form av "smarte bomber" spelte ei viktig rolle (Priest 2013).

Dei viktigaste eksterne og politiske bidraga til forhandlingsstart i 2012 var frå Venezuela sin leiar Hugo Chávez samt tilretteleggjarane Cuba og Noreg. Venezuela sin leiar, FARC sin kanskje viktigaste eksterne allierte, var viktige i å overtyde FARC om Santos sine ærlege intensjonar. ${ }^{31}$ Chávez sa òg at han ville garantere tryggleiken til FARC sin fredsdelegasjon (Goméz Giraldo 2015: 31). Timoleón Jiménez, FARCleiar frå og med 2011, understreka også at Chávez var viktig i å oppmode han til å fortsette søket etter ei politisk løysing etter drapet på FARC-leiar Alfonso Cano i 2011 (Ibid.: 30).

Noreg og Cuba var dei viktigaste tilretteleggjarane i fredsprosessen og var delaktige både før og under dei hemmelege pre-forhandlingane mellom februar og august 2012. Det er vanskeleg å bedømme kor viktig rolle dei spelte i å få framdrift i pre-forhandlingane, men det er sannsynleg at dei bidrog både til å halde prosessen hemmeleg $^{32}$ og til ein konstruktiv atmosfære samt til å overtyde FARC om at opplegget var trygt og reelt. ${ }^{33}$

Forutan direkte politiske handlingar meiner fleire respondentar at den regionale politiske konteksten på slutten av 2000-talet talte meir for ei politisk enn militær løysing på konflikten. At eit stort tal venstrevridde rørsler fekk makt gjennom politiske og ikkje-militære verkemiddel i Latin-Amerika kan ha skapt ein positiv atmosfære for fredsforhandlingar ${ }^{34}$ og viste FARC at ein kunne oppnå noko gjennom politiske verkemiddel. ${ }^{35}$ Også president Santos nemner dette som ein av dei viktigaste faktorane (Goméz Giraldo 2015: 23).

\footnotetext{
${ }^{31}$ Massé, intervju.

${ }^{32}$ García Peña, intervju.

${ }^{33}$ Nylander, intervju.

${ }^{34}$ Velandia, intervju.

${ }^{35}$ Guarin, intervju.
} 


\section{Bård Drange}

\section{Diskusjon}

$\AA ̊$ undersøke caset Colombia er viktig i seg sjølv, men kan òg gje oss betre innsikt i kvifor konfliktar sluttar generelt. Fyrst og fremst kan ein gjere dette gjennom å vise kva forhold som ikkje er nødvendige for forhandlingsstart og under kva forhold visse faktorar kan ha stor påverknad. I denne delen undersøker eg to relaterte faktorar som begge spelar ei viktig rolle i litteraturen, nemleg konfliktintensitet og rolla til leiarar.

Medan FARC gradvis kom til avgjersla om at ei politisk løysing var deira beste moglegheit for å nå nokre av dei politiske måla sine, skjedde endringa raskt hjå den colombianske staten. Ein openberr grunn til at Santos kunne stå for denne endringa, er at forgjengaren, Álvaro Uribe, hadde bygd sitt politiske prosjekt og mykje av populariteten sin på krig mot FARC. ${ }^{36}$ Likevel er ikkje det å vere ny leiar i seg sjølv nok. Det er naudsynt både å faktisk endre kurs og klare å drive fram ein levedyktig prosess.

Det at Santos ønskte å forhandle som følgje av ein attraktiv moglegheit til å nå spesifikke mål, meir enn grunna eit sterkt mandat frå folket eller militært naudsyn, er uvanleg. Ifølgje Pruitt (1997: 242) er nemleg forventingar om godar frå eit psykologisk perspektiv mindre motiverande enn forventingar om tap. Dette er også tilfellet fordi attraktive moglegheiter ofte er abstrakte, og fordi det sjeldan hastar. Deler av forklaringa på kvifor Santos likevel valde å søke forhandlingar, kan vere hans klare og konkrete målsettingar for kva fordelar og konsekvensar slutten på krigen kunne føre med. Dessutan er det svært tenkeleg, som Mitchell (1995: 45) skriv, at insentivet for å sette i gong ein fredsprosess kan vere større dersom han eller ho kan forvente å spele ei leiarrolle også i framtida.

At Santos kunne gå i dialog med FARC som ei moglegheit og ikkje politisk nødvendigheit, er tett knytt opp til den lågare konfliktintensiteten på slutten av 2000-talet enn på slutten av 1990-talet. Millionar av colombianarar var framleis internt fordrivne, men færre vart fordrivne kvart år, væpna konfrontasjonar var færre, dødsratar minka og Colombia vart ein meir stabil stat med økonomisk framgang og større statleg nærvære i distrikta (Woody 2015; UCDP 2017). Då dei colombianske styrkane i åra frå 2008 og frametter drap fleire FARC-leiarar, og FARC vart vidare svekka av demobilisering, vart den væpna konflikten ikkje lenger sett på som Colombias største utfordring. Frå 50 prosent før 2009 fall prosentdelen colombianarar som såg den væpna konflikten som det største problemet i landet til under 30 prosent i 2009, og vidare ned til 15 prosent i 2012 (Sánchez et al. 2015: 195).

\footnotetext{
${ }^{36}$ Juanita Villaveces, professor, intervju 30.11.16, Bogotá.
} 
Grafe 2: Soldatar drepne på slagmarken i konflikten med FARC

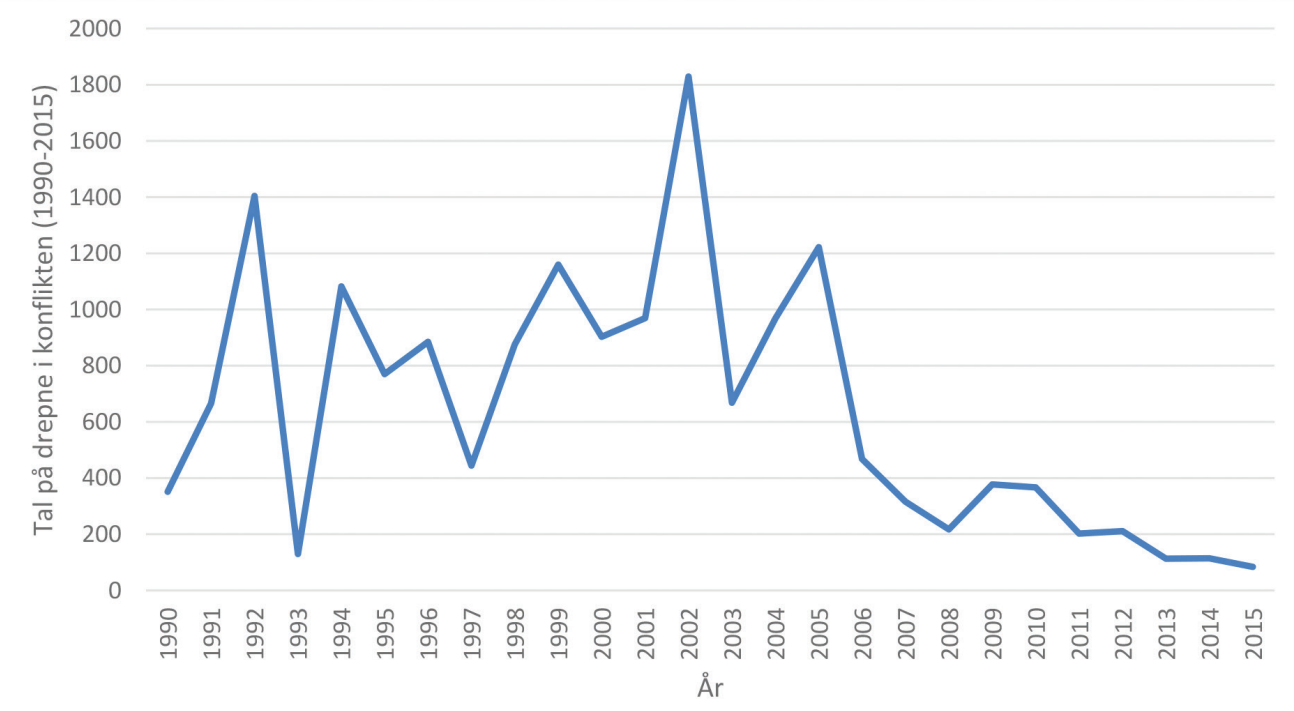

Grafe 2. Produsert med data frå UCDP (2017).

Fleire forskarar antydar at høgare konfliktintensitet kan føre til sterkare insentiv til å avslutte krigen (Mason \& Fett 1996; Urlacher 2011; Ghosn 2010). Logikken er at når kostnadane i augneblinken er små, hastar det mindre, og ein utsett og prioriterer heller meir presserande problem. Likevel kan også større potensielle kostnadar fram i tid vere ein motivasjon for å forhandle (Zartman 2000). Ein kan, med andre ord, tenke seg at viljen til den colombianske presidenten var mindre, sidan å få slutt på konflikten ikkje sto like høgt på agendaen lenger. At fredsforhandlingar likevel tok til, har mange årsaker, men det er vanskeleg å sjå føre seg ein levedyktig prosess utan den viljen og tilnærminga Santos tok med seg inn i presidentembetet.

Det initiativet Santos tok, kan sjåast på som ein enticing opportunity. Ein enticing opportunity materialiserer seg når leiarar ser betre og alternative måtar å nå måla sine på enn å fortsetje ein inkjeseiande og kostnadsfull krig (Mitchell 1995: 44). Denne moglegheita handlar meir om potensielle moglegheiter og fordelar enn om noverande og framtidige forventa kostnadar. For Santos verkar det som om økonomiske motivasjonar om auka vekst, modernisering og utanlandsinvesteringar sto sterkt, men òg sannsynlegvis ønsket om å vere den som leia landet inn i fredstid.

Som Mitchell (1995: 46) skriv, er det usannsynleg at leiarar kan sjå ein enticing opportunity når den gjenstridige konflikten er på sitt mest intensive og kostnadsfulle. I Caguán stod folket sitt desperate ønske om å få slutt på valden sentralt hjå Pastrana. Dessutan ønskte han å forsterke Colombia sitt militærvesen. Ifølgje Ghosn (2010) kan væpna aktørar ønskje forhandling av to grunnar. Det er for å nå 


\section{Bård Drange}

kortsiktige mål, for eksempel ein pause frå militære konfrontasjonar og mobilisere til vidare kamp, eller for å forhandle med intensjonar om å utkassere gevinstar lengre fram $\mathrm{i}$ tid. At kostnadane forbunde med krigen vart lågare, var nok viktige i å gje Santos moglegheita til å tenke langsiktig og ende konflikten politisk, noko Pastrana ikkje hadde.

Personfokuset på president Santos er viktig, men også komplisert. For det fyrste er det mange, mellom anna i fredsdelegasjonen og i det politiske apparatet, som spelte ei viktig rolle bak Santos. Og sjølv om Santos har ei særeigen pragmatisk og bestemt tilnærming til konflikten, er det viktige sosiale og økonomiske prosessar som òg bidrar til å forklare Santos sine synspunkt og kvifor Santos kunne lukkast med å inngå fredsforhandlingar. Det er, for eksempel, ikkje nok å sjå på Uribe og Santos som personar med to forskjellige tilnærmingar til konflikten. Ein kan òg forstå dei som to komplimenterande leiarar, som begge bidrog til forhandlingsstart. Slik eg har analysert det, ville ikkje fredsforhandlingar ha funne stad utan korkje Uribe si militære svekking av FARC eller Santos sine pragmatiske handlingar for å slutte konflikten gjennom forhandlingar.

\section{Konklusjon}

Det er utvilsamt fleire grunnar til at partane i den colombianske konflikten valde å inngå forhandlingar i 2012. I denne artikkelen undersøker eg tre: den militære maktbalansen, leiarar og tredjepartar. Av desse finn eg den militære maktbalansen viktigast, der krigen mot FARC på 2000-talet svekka geriljagruppa betydeleg og gav dei dårlege utsikter til å vinne militært. Dette motiverte FARC til å søke ei ikkjemilitær løysing. På den colombianske staten si side speler president Juan Manuel Santos ei sentral rolle. Santos er essensiell ved at han endrar staten sitt syn på konflikten og opnar opp for at FARC kan ta del i forhandlingar om sin politiske agenda. Personen og bakgrunnen til Santos er viktig når han, mot sitt politiske mandat, vrir seg vekk frå strategien til forgjengaren Uribe, mot ei potensielt svært risikabel politisk løysing, og tar pragmatiske grep for å løyse konflikten politisk. Tredjepartar spelte også ei viktig rolle, deriblant Hugo Chávez, FARC sin viktigaste eksterne allierte, samt tilretteleggjarane Cuba og Noreg.

Viljen Santos si regjering og FARC hadde for å slutte konflikten gjennom forhandlingar i 2012, har vist seg å halde seg gjennom sjølve fredsforhandlingane til signering i november 2016. Etter den tid har FARC lagt ned våpena og danna eit politisk parti. Per juli 2018 har ikkje væpna konflikt blussa opp att, men freden er likevel skjør. Fleire moment trugar freden i Colombia, inkludert manglande gjennomføring av avtalen, fleire dissidentar blant tidlegare FARC-soldatar og overtakinga av tidlegare FARC-kontrollerte områder av ulike kriminelle grupper og den andre opprørsgruppa ELN (Drange \& Lie Opdahl 2018). Valet av fredsavtale-kritikaren Iván Duque til president 17. juni 2018 skaper vidare usikkerheit, men kva implikasjonane vert for fredsprosessen er framleis usikkert. 
For å unngå oppblussing av konflikten, og for å bygge varig fred, er det avgjerande at ein no som symptomet væpna konflikt er borte, prøver å løyse underliggjande problem i Colombia. Sjølv om fleire dissidentar allereie har teke til våpen att, er det usannsynleg at FARC som gruppe gier det (ICG 2018). Dei har sett at å nå politiske mål militært er fånyttes. Likevel, dersom ein ikkje ser resultat av gjennomføringa av fredsavtalen, og dersom ein ikkje ser forbetringar i sentrale spørsmål som fordeling av jord og statleg nærvære i heile Colombia, er det sjansar for at fredsavtalen i Colombia ender blant den halvdelen av tidlegare konfliktar som bryt ut i ny konflikt innan 10 år etter underskriving av ein fredsavtale (Westendor 2015: 7).

I forsking på gjenstridige konfliktar og kvifor dei tek slutt, meiner eg case-studiar som denne kan vere nyttige. Også komparative studiar på tvers av konfliktar kan hjelpe oss å forstå dynamikkar bak kvifor væpna aktørar vel ei politisk løysing på ein væpna konflikt. Sjølv om forhandlingsstart ikkje må likestillast med fredsavtale eller slutten på konflikten, kan slike undersøkingar gje oss viktige svar på kor væpna aktørar sin motivasjon til å forhandle kjem frå, og under kva tilhøve denne motivasjonen kan bringe partane til forhandlingsbordet.

Denne studien støtter opp om tidlegare forsking sitt fokus på partane - ikkje minst leiarane - sin vilje til å forhandle. I Colombia var det dei to væpna aktørane som spelte hovudrollene og dreiv fram prosessen. Ønsket om fred hjå store deler av det colombianske folket har vore viktig etter at hemmelege fredsforhandlingar vart offentleggiort i 2012. Likevel er det eit poeng at det var større politisk press og uttalt ønskje frå den colombianske befolkninga om fredsforhandlingar i forkant av Caguán enn Havanna. Dette, at fredsforhandlingar vart sette i gang delvis i mot folkeopinionen, understrekar naudsynet av pragmatisme i møte med konfliktar med store interne rivningar og fiendskap. Dømet Colombia, som meir eller mindre ser ut til å styre vekk frå væpna konflikt, antydar at for tilsynelatande uløyselege konfliktar til å ta slutt, trengst fyrst og fremst politiske vilje samt ei pragmatisk tilnærming til konflikten.

\section{Biografi}

Bård Drange er juniorforskar i Forskningsgruppa for fred, konflikt og utvikling ved Norsk Utenrikspolitisk Institutt. Drange har mastergrad i Peace and Conflict Studies ved Universitetet i Oslo, og forsker på konfliktløysing, fredsoperasjonar og valdelege opprørsgrupper.

\section{Om artikkelen}

Artikkelen er basert på forfattaren si masteroppgåve i Peace and Conflict Studies ved Universitetet i Oslo og Norsk Utenrikspolitisk Institutt. Forfattaren ynskjer å takke vegleiarane på masteroppgåva Tora Skodvin (Universitetet i Oslo) og Benedicte Bull (Senter for utvikling og miljø), samt Malin Østevik og Morten Skumsrud Andersen for mange og gode innspel. Ein takk går også til Fritt Ord som gjennom sitt stipend 


\section{(handsama av Institutt for statsvitskap ved Universitetet i Oslo) mogleggjorde feltarbeidet i Colombia.}

\section{Bibliografi}

Acosta, Henry (2016) El hombre clave: El secreto mejor guardado del proceso de paz de Colombia. Penguin Random House Grupo Editorial: Bogotá.

Bercovitch, Jacob \& S. Ayse Kadayifci (2002) "Conflict Management and Israeli-Palestinian Conflict: The Importance of Capturing the 'right Moment", Asia-Pacific Review, 9: 113-129.

Borda Guzmán, Sandra (2012) La internacionalización de la paz y de la guerra en Colombia durante los gobiernos de Andrés Pastrana y Álvaro Uribe. Universidad de los Andes: Bogotá.

Bouvier, Virginia M. (2012) "El proceso del Caguán y la comunidad internacional” i Sandra Borda and Fernando Cepeda Ulloa (red.), Proceso de paz en Colombia: Participación de actores internacionales. Ecoe Ediciones: Bogotá.

Castro, Fidel (2008) La paz en Colombia. Editora Política: Havanna.

Chernick, Marc (2007) "FARC-EP: Las Fuerzas Armadas Revolucionarias de Colombia-Ejército del Pueblo" i Marianne Heiberg, Brendan O’Leary \& John Tirman (red.), Terror, insurgency, and the state: ending protracted conflicts. University of Pennsylvania Press: Philadelphia.

Chernick, Marc (2015) "Santos, the FARC, and the Evolution of Peace Negotiations in Colombia”, i Colombia's Political Economy at the Outset of the Twenty-First Century: From Uribe to Santos and Beyond. Lexington Books: Lanham.

Clausewitz, Carl von, Michael Howard \& Peter Paret (1984) On war. Princeton University Press: Princeton.

CNRR, Comisión Nacional de Reparación y Reconciliación (2013) ;Basta ya!: Colombia: Memorias de guerra y dignidad. Centro Nacional de Memoria Histórica: Bogotá.

Cunningham, David (2010) "Blocking resolution: How external states can prolong civil wars", fournal of Peace Research, 47: 115-127.

Drange, Bård (2017). "Peace in protracted conflicts: Explaining peace negotiation onset in the Colombian armed conflict", MA thesis. University of Oslo: Oslo.

Drange, Bård \& Maja Lie Opdahl (2018) “Colombia between peace and war: The 2018 presidential elections and the way forward", NUPI policy brief 8:2018.

Echandía, Camilo (2015) Cincuenta años de cambios en el conflicto armado colombiano (1964-2014). Universidad del Externado: Bogotá.

Egeland, Jan (2007) Det nytter: rapport fra frontlinjene. Aschehoug: Oslo.

Farah, Douglas (1999) “U.S. Ready to Boost Aid to Troubled Colombia.” Washington Post, 23.08.1999.

Fearon, James D. \& David D. Laitin (2008) “Civil war termination", paper presented at 2007 Annual Meetings of the American Political Science Association, Chicago, Illinois, 30 August-1 September.

Fearon, James D. (2004) "Why Do Some Civil Wars Last so Much Longer than Others?", fournal of Peace Research, 41: 275-301.

Fergusson, Leopoldo, James A. Robinson, Ragnar Torvik og Juan F. Vargas (2016) "The Need for Enemies", Economic fournal, 126: 1018-1054.

Fixdal, Mona (red.) (2016) Fredsmegling i teori og praksis. Cappelen Damm Akademisk: Oslo.

George, Alexander L. \& Andrew Bennett (2007) Case studies and theory development in the social sciences. MIT Press: Cambridge.

Ghosn, Faten (2010) “Getting to the Table and Getting to Yes: An Analysis of International Negotiations", International Studies Quarterly, 54: 1055-1072.

Gillespie, Patrick (2015) "Peace in Colombia could mean profit for investors", CNN 05.10.2015.

Gómez Giraldo, Marisol (2016) La historia secreta del proceso de paz. Intermedio: Bogotá.

Grenoble, Alexander \& William Rose (2011) “David Galula's Counterinsurgency: Occam's Razor and Colombia", Civil Wars, 13: 280-311.

Hopmann, P. Terrence (1998) The negotiation process and the resolution of international conflicts. University of South Carolina Press: Columbia, S.C.

ICG (2016) “Colombia's Final Steps to the End of War”, International Crisis Group.

ICG (2018) "Risky Business: The Duque Government's Approach to Peace in Colombia”, International Crisis Group.

Iklé, Fred C. (1964) How nations negotiate. Harper \& Row: New York. 
Iklé, Fred C. (2005) Every war must end. Columbia University Press: New York.

Isacson, Adam (2003) "Was failure avoidable? Learning from Colombia's 1998-2002 peace process," The Dante B. Fascell North-South Center Working Paper Series. University of Miami: Florida.

Kaplow, Jeffrey M. (2016) “The Negotiation Calculus: Why Parties to Civil Conflict Refuse to Talk", International Studies Quarterly, 60: 38-46.

Levy, Jack S. (2008) “Case studies: Types, designs, and logics of inference”, Conflict Management and Peace Science, 25: 1-18.

Licklider, Roy (1993) Stopping the Killing: How Civil Wars End. NYU Press: New York.

Mason, T. David, and Patrick J. Fett (1996) "How civil wars end: A rational choice approach", The fournal of Conflict Resolution, 40: 546-568.

Mitchell, Christopher R. (1995) “The right moment: Notes on four models of 'ripeness'”, Paradigms, 9: 38-52.

Pastrana, Andrés (2005) La Palabra Bajo Fuego. Planeta Colombiana: Bogotá.

Pécaut, Daniel (2008) Las FARC: ¿una guerrilla sin fin o sin fines?. Grupo Editorial Norma: Bogotá; Miami.

Peña, Mario Aguilera (2014) Guerrilla y población civil: La trayectoria de las FARC, 1949-2013. Centro Nacional de Memoria Histórica: Bogotá.

Pillar, Paul (2014) Negotiating peace: war termination as a bargaining process. Princeton Legacy Library: Princeton.

Posso, Camilo G. (2009) "El Caguán Irrepetible”, INDEPAZ.

Priest, Dana (2013) "Covert action in Colombia”, Washington Post 21.12.2013.

Pruitt, Dean (1997) "Ripeness Theory and the Oslo Talks", International Negotiation, 2: 237-250.

Pruitt, Dean (2005) Whither ripeness theory? George Mason University: Virginia.

Pruitt, Dean (2007) "Readiness Theory and the Northern Ireland Conflict", American Behavioral Scientist, 50 (11): 1520-1541.

Ramsbotham, Oliver, Hugh Miall, \& Tom Woodhouse (2011) Contemporary conflict resolution: the prevention, management and transformation of deadly conflicts. Polity: Cambridge.

Sánchez, Miguel G. et al. (2015) Cultura politica de la democracia en Colombia, 2014. Vanderbuilt University: Appleton Place.

Stedman, Stephen J. (1997) "Spoiler problems in peace processes", International Security, 22: 5-53.

Stein, Janice G. (1989) Getting to the table: The processes of international prenegotiation. Johns Hopkins University Press: Baltimore.

Tate, Winifred (2015) Drugs, thugs, and diplomats: U.S. policymaking in Colombia. Stanford University Press: Stanford.

UCDP (2017) "UCDP Conflict encyclopedia” i UCDP Conflict encyclopedia. Uppsala: Uppsala Conflict Data Program, Uppsala University.

Urlacher, Brian R. (2011) "Political Constraints and Civil War Conflict Resolution", Civil Wars, 13: 81-98.

Vargas Velásquez, Alejo (2012) Las fuerzas armadas en el conflicto colombiano: Antecedentes y perspectivas. La Carreta Editores: Medellín.

Westendorf, Jasmine-Kim (2015) Why Peace Processes Fail: Negotiating Insecurity After Civil War. Lynne Rienner: Boulder.

WOLA, Washington Office on Latin America (2016) "U.S. Aid Over the Years" tilgjengeleg på https://www. wola.org/files/1602_plancol/content.php?id=us_aid. Lesedato 01.05.2017.

Woody, Christopher (2015) "Colombia must now "contemplate the risk that peace will not be secured", Business Insider 11.04.2017.

Zartman, I. William \& Maureen R. Berman (1982) The practical negotiator. Yale University Press: New Haven.

Zartman, I. William (2000) "Ripeness: The Hurting Stalemate and Beyond” i Druckman Daniel \& C. Stern Paul (red.), International Conflict Resolution After the ColdWar. National Academies Press: Washington. 


\begin{abstract}
English
The conflict in Colombia has seemed insolvable for decades. Despite several peace attempts, it has always flared up again. In this article, I explain the onset of peace negotiations in 2012 between the Government of Colombia and the FARC, the largest guerrilla group in the country. I claim the fundamental explanation for why they initiated negotiations was the military weakening of the FARC in the 2000s, which led the guerrilla group to appreciate the necessity of ending the conflict through negotiation in order to reach at least some of their goals. The second most important factor was the change in leadership in Colombia, where in 2010 the newly-elected president, Juan Manuel Santos, considered a political solution possible and more attractive than his predecessor did, and took pragmatic measures to create a sustainable process. In addition, third parties contributed to safe and secret proceedings and to trust in the peace process. Negotiations begun in 2012 are - through a structured, focused comparison - compared with the peace dialogue in Caguán (1999-2002) between the same actors, where negotiation did not start. Case studies like this one can help us understand dynamics behind the choices of armed actors to pursue political solutions to armed conflicts. The onset of negotiation, which I analyze, must not be equated with a peace agreement or the end of the conflict. It can, however, provide important answers about where armed actors' motivation to end conflicts come from, and under what conditions this motivation can bring the parties to the negotiating table.
\end{abstract}

Keywords: peace negotiations · armed groups • conflict resolution • Colombia 